\title{
Potential Hepatic Protection by Erythropoietin and Ischemic Conditioning in a Rat Model of Renal Ischemia-Reperfusion Injury
}

\author{
MAHER N. IBRAHIM, M.D.; AZZA A. MEGAHED, M.D.; MAHA A. FATHY, M.D. and \\ HUDA G. MOHAMED, M.Sc. \\ The Department of Medical Physiology, Faculty of Medicine, Zagazig University, Zagazig, Egypt
}

\begin{abstract}
Background: Renal ischemia reperfusion injury is a common consequence of many clinical conditions including renal transplantation, sepsis, trauma, and shock and usually leads to acute kidney injury. Its adverse effects extend to other organs including the liver leading to remote organ injury. Erythropoietin and ischemic conditioning have an antiinflammatory, anti-oxidant and anti-apoptotic effects and were reported to have a protective effect against ischemia reperfusion injury in different organs.
\end{abstract}

Aim of the Study: To evaluate the possible protective effect of erythropoietin and ischemic conditioning on the liver following renal ischemia reperfusion injury and to declare some of the possible mechanisms involved.

Material and Methods: This study was conducted on 66 adult male albino rats divided into 6 equal groups: Group I: Sham group; Group II: Renal ischemia reperfusion group (I/R); Group III: Erythropoietin pre-treatment renal ischemia reperfusion group (EPO pre-I/R); Group IV: Erythropoietin post-treatment renal ischemia reperfusion group (EPO postI/R); Group V: Ischemic pre-conditioning-renal ischemia reperfusion group (IPC) and Group VI: Ischemic postconditioning-renal ischemia reperfusion group (IPOC).

Results: Group II showed significant increase in serum creatinine, blood urea, blood urea nitrogen, AST and ALT levels with significant increase in renal and hepatic injury score indicating renal and hepatic injury following renal ischemia reperfusion. In the same group, a significant increase in serum IL6, TNFa, MDA and a significant decrease in serum SOD were found. Both group III and IV revealed a significant decrease in serum creatinine, blood urea, blood urea nitrogen, AST, ALT, renal and hepatic injury score. Levels of IL6, TNFa, and MDA significantly decrease and SOD significantly increased in both groups relative to group II and these changes were significantly higher in group III relative to group IV. In group V and VI, a significant decrease in serum creatinine, blood urea, blood urea nitrogen and renal injury score was found in both groups, while serum AST, ALT and hepatic injury score were significantly decreased in group VI but remained insignificantly changed in group V versus group II. Serum IL6 and TNFa significantly decreased in both groups, while MDA significantly decreased and SOD significantly

Correspondence to: Maha A. Fathy,

Email:y maha m@hotmail.com increased in group VI only and no significant change was noticed in group V versus group II.

Conclusion: Erythropoietin pre and post treatment significantly improved renal and hepatic function and morphology following renal ischemia reperfusion injury with better results for erythropoietin pre-treatment. Ischemic post-conditioning induced significant decrease in renal and hepatic injury, while ischemic pre-conditioning provided renal protective effect which didn't extend to involve the liver.

Key Words: Ischemia-Reperfusion-EPO-IPC-IPOC.

\section{Introduction}

ISCHEMIA reperfusion (I/R) injury is caused by limitation of blood flow to an organ followed by reestablishment of blood flow and re-oxygenation. It is evidenced now that the restoration of blood flow which occurs after an ischemic attack in an organ produces more injury to the tissues than that produced by ischemia itself [1]. Renal I/R injury is the most common cause of acute kidney injury (AKI). It is a serious clinical challenge that occurs in many clinical cases as renal transplantation, trauma, sepsis and shock $[2,3]$ and induces renal dysfunction with high morbidity and mortality rates $[4,5]$. The pathogenic mechanisms underlying renal I/R injury are complex that include release of reactive oxygen species (ROS), necrosis, cell apoptosis, inflammation and cytokines release, but the exact mechanisms are unclear [5]

Further studies showed that harmful effects of renal I/R are not limited to the kidney, but extend to other organs including liver [6], lung [7], brain [8], heart [9] and gut [10] leading to what is called remote organ injury (ROI), in a process of organ crosstalk by which AKI can lead to multiple organ dysfunction or even failure [10,11].

Liver is one of the remote organs commonly affected during renal I/R injury. However, limited 
clinical data are found on the effect of AKI on liver function. Liver dysfunction and AKI commonly coexists together, particularly in the intensive care unit with higher mortality rate [10]. Liver is very important for metabolic function in critically ill patients including drug metabolism. So, liver injury along with renal injury further complicates the efficacy of treatment in intensive care unit [12] Humoral and/or cellular factors are thought to be the cause of hepatic injury secondary to I/R. Previous studies have shown that acute kidney injury causes an increase in leukocytic infiltration and induces oxidative stress in the liver resulting in hepatic dysfunction $[\mathbf{6 , 1 3 , 1 4 ]}$.

Erythropoietin (EPO) is a hypoxia-induced Hormone that promotes erythropoiesis. Independent of its role in regulation of erythropoiesis, EPO has anti-oxidative, anti-apoptotic and pro-angiogenic effects [15-17]. The presence of EPO receptors in renal tubular and mesangial cells indicates a crucial role for EPO in renal function. Furthermore, in vivo animal studies of kidney injury, EPO ameliorated the changes in renal function and histology fundamentally via its anti-apoptotic effects [18] EPO has been shown to protect different organs including brain, heart, and kidney against I/R injury [19].

Gul and his team [20] demonstrated that, systemic administration of high-dose erythropoietin promotes regeneration of hepatic tissue by affecting biochemical and histopathological parameters after liver resection. Moreover, Schmeding et al., [21] reported an increase of regenerative capacity in EPO treated rats after major hepatectomy. In another study, erythropoietin was reported to reduce hepatic ischemia-reperfusion injury after liver transplantation in rats [22]. These data indicate the possibility of a protective role for erythropoietin in attenuation of hepatic damage after renal ischemia reperfusion injury.

One of the currently most effective therapies to counteract the damage induced by ischemia reperfusion injury is the ischemic conditioning techniques [23-25]. The conditioning stimulus can be applied before (ischemic preconditioning) or after (ischemic post-conditioning) the major ischemic event. Ischemic conditioning is associated with tissue protection not only in normal physiology, but in both animal models and in humans with ischemia reperfusion syndromes [26,27]

Several studies have shown the beneficial effects of pharmacological and ischemic pre and postconditioning in different ischemia reperfusion models [28]. However, the post-conditioning excels for its greatest clinical applicability compared to pre-conditioning as the ischemic insult is difficult to be predicted $[29,30]$. Besides, the direct protective effect of different methods of pharmacological or ischemic conditioning on the kidney or the liver themselves was frequently investigated [31]. However few studies evaluated the protective effect of these methods on the liver as a remote organ injured following renal ischemia reperfusion injury. So, this study was designed to evaluate the possible protective effect of erythropoietin (EPO) (pre and post-treatment) and ischemic (pre and post conditioning) on hepatic injury induced by renal ischemia reperfusion injury and demonstrate the effect of these interventions on some markers of tissue inflammation, oxidative stress, renal and hepatic function and histopathology

\section{Material and Methods}

Animals: From October 2016 to July 2017, this study was conducted on 66 healthy adult male albino rats, $12-15$ weeks old weighing 230-280g, obtained from animal house of Zagazig University. The rats were placed in steel wire cages $(50 \times 30$ $\mathrm{x} 20 \mathrm{~cm}), 4$ rats per cage. They were housed at standard conditions $\left(25-30^{\circ} \mathrm{C}\right.$, natural dark/light cycle), and received food and water ad libitum. The animals were left to acclimatize for one week, and then the animals were divided into 6 equal groups:

Group I: Sham group, in which rats were subjected to sham operation (laparotomy without occlusion of renal pedicles).

Group II: Renal ischemia reperfusion group (I/R), in which rats were subjected to bilateral renal ischemia reperfusion protocol where bilateral renal ischemia was done by occlusion of the renal pedicles of both kidneys for $45 \mathrm{~min}$ followed by reperfusion for $12 \mathrm{hs}$ [12]

Group III: Erythropoietin-renal ischemia reperfusion pre-treatment group (EPO pre-I/R), in which rats received single intra-peritoneal injection of epoetin (1000 IU/kg) (SEDICO, Egypt) $30 \mathrm{~min}$ prior to I/R protocol [8] .

Group IV: Erythropoietin-renal ischemia reperfusion post-treatment group (EPO post-I/R), in which rats received single intra-peritoneal injection of epoetin (1000 IU/kg) 60min after I/R protocol [32].

Group V: Ischemic preconditioning group (IPC), in this group renal ischemia reperfusion protocol was immediately preceded by 4 cycles each consisted of $10 \mathrm{~min}$ of renal ischemia followed by 10 min of reperfusion [33]. 
Group VI: Ischemic post conditioning group (IPOC), in this group immediately after $45 \mathrm{~min}$ of renal ischemia, rats were accounted for 6 cycles each consisted of 10s of renal reperfusion followed by 10 s of renal ischemia before final reperfusion for $12 \mathrm{hs}$ [34].

Death rate among groups was $\sim 10 \%$ and these rats were replaced.

The experimental procedures used in this study were in accordance with the guiding principles for the care and use of research animals and were approved by the Institutional Research Board of Faculty of Medicine, Zagazig University.

Surgical procedure: Rats were anesthetized with i.p injection of pentobarbital $(45 \mathrm{mg} / \mathrm{kg}$ ) then heparin (500 units) (Nile Co, Egypt) was given by i.p injection to prevent intravascular blood clotting [35]. After stabilization of anaesthesia, the rats were placed on a board in the supine position over an electric heated pad and body temperature was monitored with a rectal probe and maintained at $37^{\circ} \mathrm{C}$ then, a midline laparotomy incision was made, and the renal pedicles were identified and isolated carefully. In the ischemic groups, a non-traumatic vascular clamp was placed around both right and left renal pedicles for $45 \mathrm{~min}$, followed by $12 \mathrm{hs}$ of reperfusion. Successful ischemia was judged by change in tissue colour from bright red to dark blue, after clamp removal, kidneys were observed for restoration of blood flow by regaining their original colour. Sham-operated animals underwent identical surgical procedure, including isolation of both renal arteries but without occlusion of renal pedicles [12]

Measurement of Blood Pressure (MAP): After an overnight fasting, urethane $(1200 \mathrm{mg} / \mathrm{kg}$ ) was used to anesthetize the rat [36]. After shaving the skin on the ventral side of the neck, chest and right hind leg, small incision was made in the rat neck for tracheostomy and cannulation of carotid artery [37]. For cannulation of carotid artery, a cannula pre-filled with heparinized normal saline $(0.5$ $\mathrm{IU} / \mathrm{ml}$ ) was used. A three-way stopcock connected to a pressure transducer was connected to the other end of the cannula. After calibration using a sphygmo-manometer, the animal was connected to the Power Lab for BP recording. The procedure was left for $10-20 \mathrm{~min}$ to stabilize during which the rat was continuously monitored for any bleeding [37]

Blood sampling: At the end of $12 \mathrm{hs}$ reperfusion phase, arterial blood pressure was measured then animals were sacrificed by decapitation and blood samples $(5-8 \mathrm{ml} / \mathrm{rat})$ were obtained. Blood was allowed to clot at room temperature then centrifuged at 3000rpm for $15 \mathrm{~min}$ and serum was stored at $-20^{\circ} \mathrm{C}$ till biochemical assay.

\section{Biochemical Analysis:}

Serum creatinine level: was calorimetrically measured according to Murray et al., [38] using (Spinreact, S.A.U. ctra. Santa Coloma, 7e-17176 Santest eve de bas (gi), Spain).

Serum urea level: Was calorimetrically measured according to Kaplan [39] using (Spinreact, S.A.U. ctra. Santa Coloma, 7e-17176 Sant esteve de bas (gi), Spain).

Blood urea nitrogen (BUN): Was assessed by enzymatic method according to Flavio \& William [40] (modified Berthelot reaction) (dp international; Tuscaloosa: USA).

Serum aspartate aminotransferase (AST): According to Rec [41] by using rat AST enzyme-linked immunosorbent assay kit, (Catalog Number: 201111-0595, Shanghai Sunred biological technology, China).

Serum alanine aminotransferase (ALT): According to Rec [41] by using rat ALT enzyme-linked immunosorbent assay kit, (Catalog Number: 201111-0595, Shanghai Sunred biological technology, China).

Serum IL-6: Was measured by rat IL-6 ELISA kits according to assay instructions (Sigma-Aldrich Company Ltd, Egypt).

Serum TNF a: Using rat ELISA kits according to Engelberts et al., [42] (Elabscience Biotechnology, USA. Cat: EEL-H0109).

Serum superoxide dismutase (SOD): Using superoxide dismutase (SOD) assay kits (SigmaAldrich Company Ltd, Egypt. Cat: 19160)

Serum malondialdehyde (MDA): Using lipid perioxidation (MDA) assay kits (Sigma-Aldrich Company Ltd, Egypt. Cat: MAK085).

Histopathological examination: Kidneys and liver were harvested and bisected longitudinally into 3 equal sized slices then fixed in $10 \%$ formalin solution. After automated dehydration kidney and liver slices were embedded in paraffin, sectioned by microtome at 5um and stained with hematoxylineosin (HE) stain for blind histopathological examination.

Histopathological scoring: The renal histopathology was examined for the following parameters: 
Tubular cell degeneration, exfoliated cells in the lumen, intra-luminal casts, vascular congestion, hydropic degeneration and inflammatory cell infiltration.

Hepatic histopathology was examined for the following parameters: Dilated congested central vein, cellular degenerative changes, cytoplasmic vacuolization, leukocytic infiltration and cellular necrosis.

The samples were scored at 1-5 according to the severity of tissue damage as follow: Scoring 0 with no changes, 1 with less than $20 \%, 2$ with $20-40 \%, 3$ with $40-60 \%$, 4 with $60-80 \%$, and 5 with more than $80 \%[43,44]$

\section{Statistical analysis:}

The data were expressed as mean $\pm \mathrm{SD}$. For quantitative variables, one way ANOVA followed by post hoc test with LCD was done to compare means. $p$-values $<0.05$ were considered significant. The statistical analysis was done by using SPSS program (version 18 for windows) (SPSS Inc. Chicago, IL, USA).

\section{Results}

Renal and hepatic function: Group II showed a significant increase in serum creatinine, blood urea, BUN, AST and ALT compared to shame group $(p<0.001)$. These levels significantly decreased in group III and IV $(p<0.001$ and $p<0.01$ respectively). Group V and VI revealed significant reduction of serum creatinine, blood urea and BUN compared to group II $(p<0.05$ and $p<0.01$, respec- tively). Serum AST and ALT significantly decreased in group VI $(p<0.01)$ but no significant difference was found in these levels in group $\mathrm{V}$ relative to group II $(p>0.05)$ (Table 1).

Inflammatory markers: A significant increase in IL-6 and TNF $\alpha$ was found in group II relative to group I $(p<0.001)$. Both levels decreased significantly in group III, IV, V and VI versus group II $(p<0.001, p<0.01, p<0.01$ and $p<0.05$ respectively) (Table 1).

Oxidative stress markers: MDA levels significantly increased in I/R group versus sham group $(p<0.001)$. MDA levels significantly decreased in group III, IV and VI compared to I/R group ( $p<0.01$, $p<0.01$ and $p<0.05$ respectively). No significant difference in MDA level was found in group $\mathrm{V}$ versus group II $(p>0.05)$ (Table 1).

On the other hand, SOD levels significantly decreased in group II versus group I $(p<0.001)$. Group III, IV and VI showed significantly higher level of SOD relative to group II $(p<0.01)$. In group $\mathrm{V}$, SOD levels were not significantly different versus group II $(p>0.05)$ (Table 1).

Mean arterial pressure (MAP): A significant reduction in MAP was noticed in group II relative to group I $(p<0.05)$. EPO treatment in group III and IV induced significant elevation of MAP relative to group II $(p<0.05)$ but no statistically significant difference was found relative to group I (sham group) ( $p>0.05)$. No significant difference in MAP was recorded in group $\mathrm{V}$ and VI relative to group II $(p>0.05)$ (Table 1).

Table (1): Biochemical and biological parameters measured in all studied groups.

\begin{tabular}{|c|c|c|c|c|c|c|}
\hline $\begin{array}{l}\text { Groups } \\
\text { Parameters }\end{array}$ & GroupI & Group II & Group III & Group IV & Group V & Group VI \\
\hline Serum creatinine $(\mathrm{mg} / \mathrm{dl})$ & $0.6 \pm 0.1$ & $2.08 \pm 0.31 * \mathbf{a}$ & $1.27 \pm 0.18 * \mathbf{a}, \mathbf{b}$ & $1.6 \pm 0.08 * \mathbf{a}, \mathbf{b}, \mathbf{c}$ & $1.74 \pm 0.06^{* a, b, b}, \mathbf{c}$ & $1.57 \pm 0.22 * \mathbf{a}^{\prime} \mathbf{b}^{\prime} \mathbf{c}$ \\
\hline Blood urea (mg/dl) & $11.6 \pm 0.8$ & $27.07 \pm 0.67 * \mathbf{a}$ & $16.4 \pm 2.84 * \mathbf{a}, \mathbf{b}$ & $23 \pm 1.63 * \mathbf{a}, \mathbf{b}, \mathbf{c}$ & $23.57 \pm 1.64 * \mathbf{a}^{\prime} \mathbf{b}^{\prime} \mathbf{c}$ & $22.7 \pm 1.81 * \mathbf{a}, \mathbf{b}, \mathbf{c}$ \\
\hline BUN (mg/dl) & $6.8 \pm 0.4$ & $13.2 \pm 0.42 * \mathbf{a}$ & $9.02 \pm 0.15^{* \mathbf{a}, \mathbf{b}}$ & $11 \pm 0.94 * \mathbf{a}, \mathbf{b}, \mathbf{c}$ & $11.8 \pm 1.4^{*} \mathbf{a}, \mathbf{b}, \mathbf{c}$ & $10.9 \pm 0.89 * \mathbf{a}^{\prime} \mathbf{b} \mathbf{c}^{\prime} \mathbf{c}$ \\
\hline AST (IU/L) & $76.6 \pm 3.9$ & $262.5 \pm 7.5 * \mathbf{a}$ & $185.5 \pm 4.25 * \mathbf{a} \cdot \mathbf{b}$ & $245.5 \pm 4.85 * \mathbf{a}, \mathbf{b}, \mathbf{c}$ & $253.2 \pm 7.7 * \mathbf{a} \mathbf{c}$ & $246.8 \pm 7.5 * \mathbf{a}, \mathbf{b}, \mathbf{c}$ \\
\hline ALT (IU/L) & $16.8 \pm 0.8$ & $72.7 \pm 1.48^{*} \mathbf{a}$ & $51.37 \pm 6.79 * \mathbf{a}, \mathbf{b}$ & $63.27 \pm 3.08 * \mathbf{a}, \mathbf{b}, \mathbf{c}$ & $67.37 \pm 2.7 * \mathbf{a}^{\prime} \mathbf{c}$ & $63.35 \pm 3.8^{*} \mathbf{a}^{\prime} \mathbf{b}^{\prime} \mathbf{c}$ \\
\hline IL6 (pg/ml) & $122.4 \pm 7.6$ & $270.3 \pm 9.6^{*} \mathbf{a}$ & $180.9 \pm 16.9 * \mathbf{a} \cdot \mathbf{b}$ & $242.4 \pm 9.5 * \mathbf{a}, \mathbf{b}, \mathbf{c}$ & $248.7 \pm 6.4 * \mathbf{a}^{\prime} \mathbf{b}^{\prime} \mathbf{c}$ & $242 \pm 9 * \mathbf{a}^{\prime} \mathbf{b} \cdot \mathbf{c}$ \\
\hline $\mathrm{TNF} \alpha(\mathrm{pg} / \mathrm{ml})$ & $0.651 \pm 0.08$ & $1.03 \pm 0.13 * \mathbf{a}$ & $0.692 \pm 0.14^{*} \mathbf{b}$ & $0.79 \pm 0.11 * \mathbf{b}$ & $0.83 \pm 0.05 * \mathbf{a}, \mathbf{b}$ & $0.76 \pm 0.06^{*} \mathbf{b}$ \\
\hline MDA (nmol/ml) & $7.8 \pm 0.7$ & $18.47 \pm 1.07 * \mathbf{a}$ & $15.97 \pm 0.97 * \mathbf{a}^{\prime} \mathbf{b}$ & $16.57 \pm 0.92 * \mathbf{a}, \mathbf{b}$ & $17.55 \pm 0.51 * \mathrm{a}$ & $16.8 \pm 0.57 * \mathbf{a}^{\prime} \mathbf{b}$ \\
\hline SOD (IU/ml) & $341.7 \pm 3.6$ & $236.7 \pm 11.32 * \mathbf{a}$ & $262.8 \pm 10 * \mathbf{a}, \mathbf{b}$ & $260.8 \pm 8.7 * \mathbf{a}, \mathbf{b}$ & $232 \pm 5.4 * \mathbf{a} \mathbf{c}^{\prime} \mathbf{d}$ & $264 \pm 14.4 * \mathbf{a}, \mathbf{b}, \mathbf{e}$ \\
\hline MAP (mmHg) & $109.5 \pm 2.6$ & $95.3 \pm 4.9 * \mathbf{a}$ & $105.3 \pm 4.9 * \mathbf{b}$ & $104.5 \pm 3.7 * \mathbf{b}$ & $93.3 \pm 2.6^{*} \mathbf{a} \mathbf{c}$ & $93 \pm 2.2 * \mathbf{a}, \mathbf{c}$ \\
\hline
\end{tabular}

*: Significant $(p<0.05)$. a: Versus (I). b: Versus (II); c: Versus (III). d: Versus (IV). e: Versus (V). 
Renal and hepatic Histopathology: I/R group revealed a significant increase in both renal and hepatic injury score (Fig. 1b,2b) relative to sham group (Fig. 1a,2a) $(p<0.001)$ (Table 2). Group III, IV, $\mathrm{V}$ and $\mathrm{VI}$ showed significant reduction in renal injury score (Fig. $1 \mathrm{c}-\mathrm{f})(p<0.001, p<0.01, p<0.05$ and $p<0.01$ respectively). As regard hepatic injury score, group III, IV and VI showed significant reduction in hepatic injury score (Fig. 2c,d,f) $(p<0.01, p<0.05$ and $p<0.01$ respectively) relative to I/R group (Table 2), while in group V (IPC), no significant improvement was detected in hepatic injury score relative to I/R group (Fig. 2e) $(p>0.05)$ (Table 2).

Table (2): Renal and hepatic histopathological score in all studied groups.

\begin{tabular}{lclllll}
\hline Groups Parameters & Group I & Group II & Group III & Group IV & Group V & Group VI \\
\hline Renal & 0 & $4 \pm 0.82 * \mathbf{a}$ & $1.25 \pm 0.96^{*} \mathbf{a} \cdot \mathbf{b}$ & $1.75 \pm 0.96^{*} \mathbf{a} \cdot \mathbf{b}$ & $2.5 \pm 1.3 * \mathbf{a}^{\prime} \mathbf{b}$ & $1.5 \pm 0.58^{*} \mathbf{a} \mathbf{b}$ \\
Hepatic & 0 & $3 \pm 0.8 * \mathbf{a}$ & $0.75 \pm 0.12 * \mathbf{a}^{\prime} \mathbf{b}$ & $1.5 \pm 0.58^{*} \mathbf{a} \cdot \mathbf{b}$ & $2.75 \pm 0.96 * \mathbf{a}^{\prime} \mathbf{c}$ & $1 \pm 0.82 * \mathbf{a}^{\prime} \mathbf{b} \mathbf{e}$ \\
\hline
\end{tabular}

*: Significant $(p<0.05)$. a: Versus (I). b: Versus (II); c: Versus (III). d: Versus (IV). e: Versus (V).
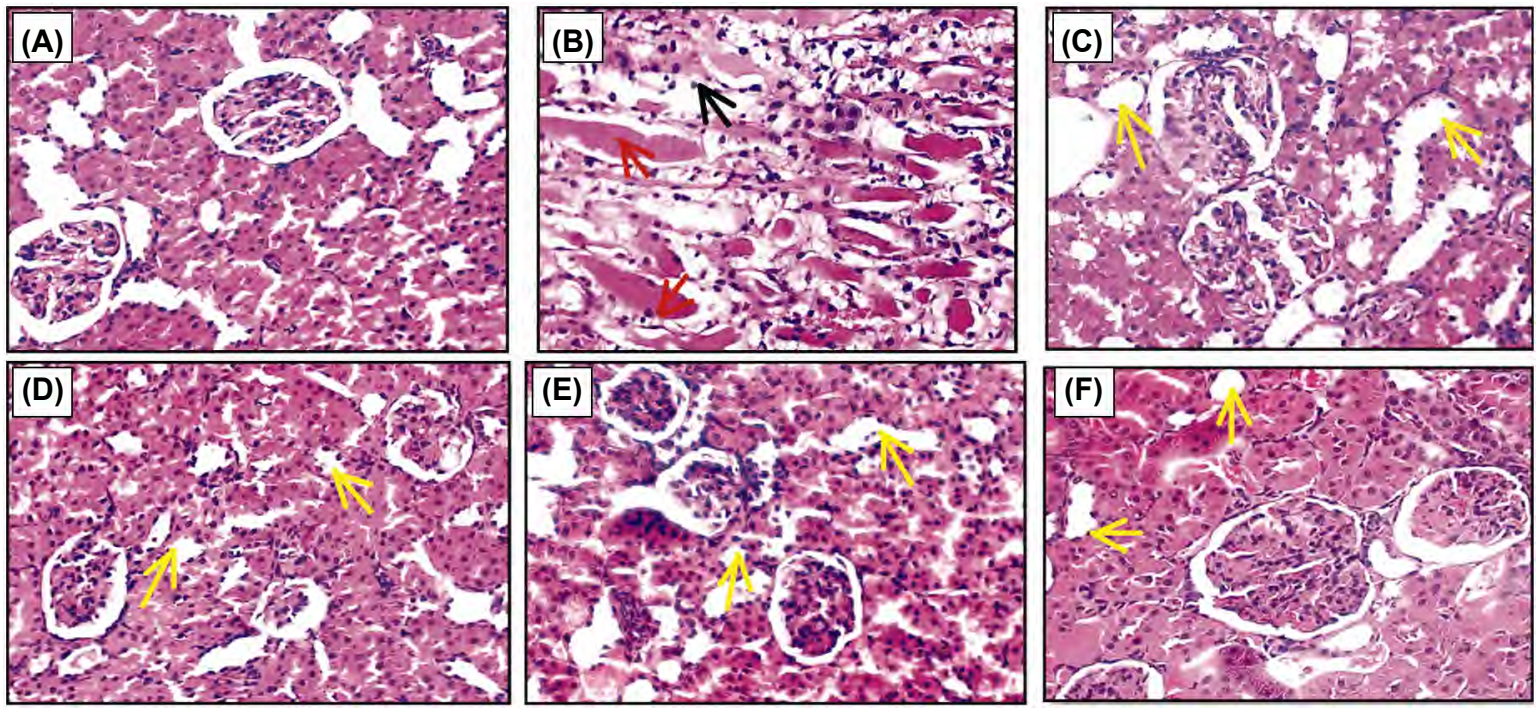

Fig. (1): Photomicroscopic pictures of kidney tissue stained with Haematoxylin \& Eosin and viewed under high power magnification x400 (1a): Sham group, showing normal sized renal glomeruli and tubules lined by cuboidal epithelial cells with well-defined cell membrane and central nuclei; (1b): I/R group, ischemic renal tissue showing renal tubules with sloughed epithelial lining (black arrow) and numerous eosinophilic casts in the lumen (red arrow); (1 c-f): (EPO pre-I/R group, EPO post-I/R group, IPC and IPOC respectively) showing return of normal architecture of renal glomerular and tubular endothelial cells with mild hydropic degeneration of the renal tubular epithelial cells (yellow arrow).
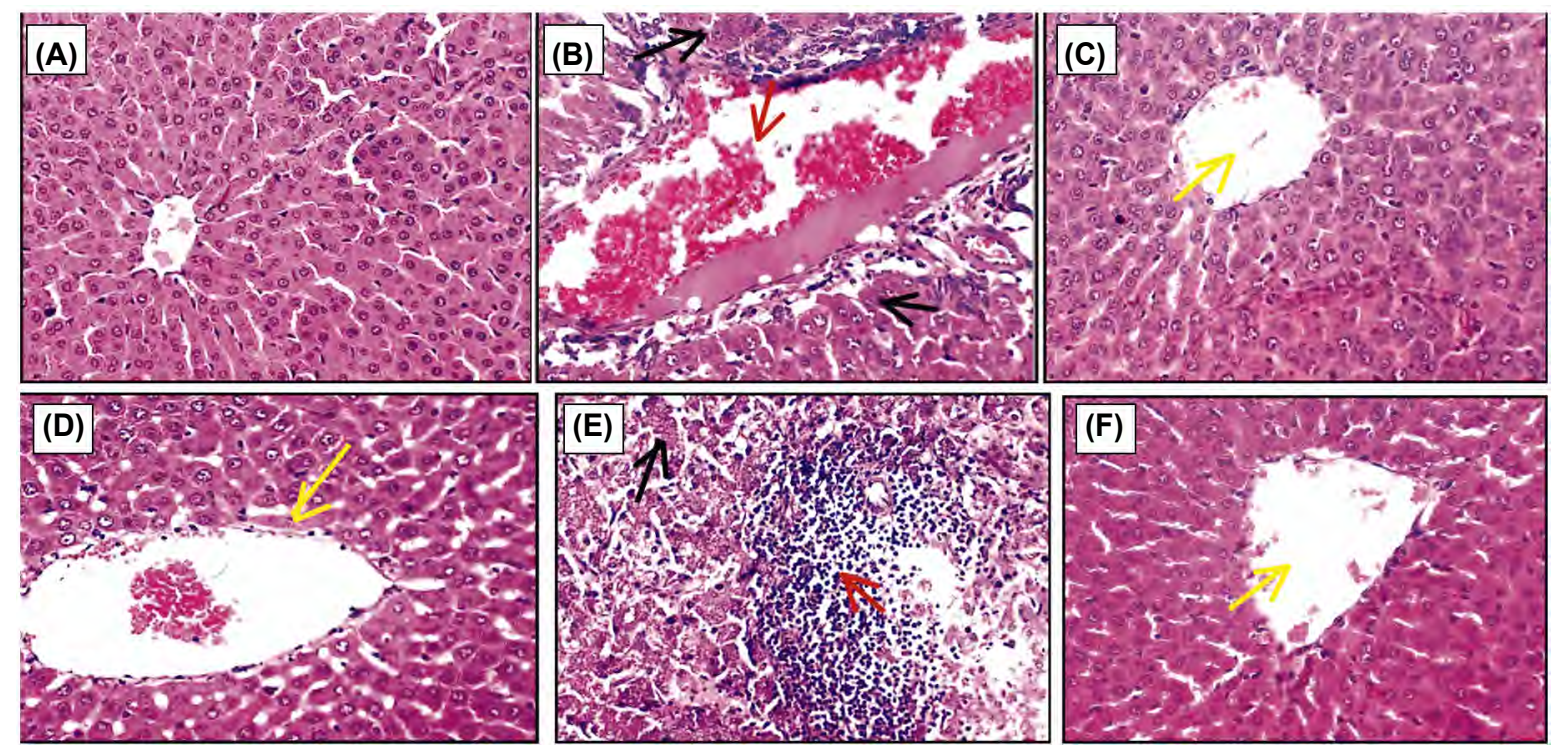

Fig. (2): Photomicroscopic pictures of hepatic tissue stained with Haematoxylin \& Eosin and viewed under high power magnification x400. (2a): Sham group, showing normal sized central vein surrounded by rows and cords of polyhedral hepatocytes with central nuclei and abundant cytoplasm; (2b): I/R group, showing dilated congested central vein surrounded by atrophic hepatocytes (black arrow) and aggregates of inflammatory cells (red arrow); (2c, 2d, 2f): (EPO pre-I/R group, EPO post-I/R group and IPOC respectively) showing normal hepatic outline with average hepatocytes but still mildly dilated central vein (yellow arrow); (2e): IPC group showing atrophic hepatocytes (black arrow) separated by heavy aggregates of inflammatory cells (red arrow). 


\section{Discussion}

After exposure of an organ to ischemic insult, restoration of blood flow is the only way to stop the ischemic cascade. However, reperfusion may result in reactive oxygen species formation and increase in inflammatory reaction which can induce tissue damage greater than ischemia itself $[28,45]$ Renal ischemia reperfusion injury (I/R) is a common result of clinical procedures such as renal resection, transplantation, trauma, sepsis and shock $[2,3]$. It is the most common cause of acute kidney injury (AKI) $[4,5]$. Remote organ injury after renal ischemia reperfusion affects many organs including lung, heart, brain, liver and gut not only by releasing injurious mediators and development of systemic inflammation but also by accumulation of numerous plasma factors normally cleared by the kidney and establishing systemic uremia which complicate the situation up to multi-organ failure $[46,47]$.

The results of this work revealed that, ischemia reperfusion injury induced marked deterioration of renal function indicated by significant elevation of serum creatinine, blood urea and BUN in I/R group relative to shame group. Serum levels of AST and ALT were significantly elevated in I/R group indicating hepatic tissue injury. Renal and hepatic histopathological score in I/R group is significantly higher than sham group. Renal tissue morphological changes revealed severe acute tubular damage indicated by the presence of sloughed epithelial cells, intraluminal eosinophilic proteinaceous casts, hydropic degeneration and inflammatory cell infiltration, while hepatic tissue morphological changes included dilated congested central veins surrounded by atrophic hepatocytes with aggregates of inflammatory cells around bile ducts and mild fatty changes of some hepatocytes.

Hepatic injury after renal I/R injury was reported by numerous investigators $[\mathbf{6 , 4 8}]$. In addition, Golab and his team [12] detected hepatic tissue damage and elevated AST, ALT, lactate dehydrogenase, and bilirubin levels after both renal I/R and bilateral nephrectomy. Besides, many studies from intensive care unit reported an association between AKI and elevated markers of liver cell damage with high mortality rates $[\mathbf{4 9 , 5 0 ]}$

The mechanisms involved in this kidney-liver cross-talk include several inflammatory and apoptotic pathways. Both renal I/R and bilateral nephrectomy were reported to induce uncontrolled expression of interleukin-17A in the liver and small intestines [48]. IL-17A is a pro-inflammatory cytokine that causes neutrophil recruitment, activation of $\mathrm{T}$ cells and induces expression of other cytokines and chemokines including TNF- $a$ and IL-6 in liver tissue [51-53]. TNFa, IL-17A, and IL-6 knockout mice and wild-type mice treated with antibodies against these cytokines showed a decrease in hepatic injury after renal ischemia [48]. These reports are in line with our results which revealed a significant increase in IL6 and TNF a in I/R group. Other mediators were also reported to be involved in renal induced hepatic damage as IL-10, intracellular adhesion molecule-1, and monocyte chemoattractant protein [54]. In addition, after experimental AKI, an increase in activated caspase-3 staining in hepatocytes and increased TUNEL positivity in the peri-portal region were reported indicating a role for apoptosis in hepatic tissue injury $[48,55]$.

The results of the present study also revealed a significant increase in malondialdehyde (MDA), an index of lipid peroxidation which is a major source of oxidative stress, and a significant reduction in SOD in I/R group; these findings indicate an increase in oxidative stress and a decrease in antioxidants. Renal ischemia was previously reported to induce hepatic oxidative stress associated with decreased levels of superoxide dismutase, catalase and total glutathione and increases in hepatic MDA [6,12]

EPO treatment either before (group III) or after (group IV) renal ischemia reperfusion provided a significant improvement in renal function indicated by a significant decrease in serum creatinine, blood urea and BUN relative to I/R group. A significant improvement of hepatic injury was also detected as proved by a significant decrease in AST and ALT levels. Histopathological examination of EPO treated rats showed significant improvement of the renal glomerular and tubular epithelial cell damage versus I/R group. Liver tissue injury was also improved significantly compared to I/R group with return to normal hepatic architecture with mildly dilated central vein. The results also revealed that, EPO pre-treatment provided significantly better results than EPO post-treatment. In group III, EPO was given before ischemia reperfusion takes place and so, its protective effect started very early through its anti-inflammatory, anti-oxidative, antiapoptotic and pro-angiogenic properties [15-17] but in group IV, EPO was given after the insult of ischemia reperfusion when renal and hepatic tissue were already injured and it is well identified that, the early moments of ischemia reperfusion are detrimental in the pathogenesis of post-ischemic injury [56], nevertheless, the protective effect of EPO post-treatment group was still statistically 
significant. This is in line with previous reports indicated that, the protective effect of EPO was still apparent even when administration is delayed up to $6 \mathrm{~h}$ after the onset of injury [57]. Although less effective, EPO post treatment has greater clinical applicability than EPO pre-treatment because the ischemic insult is difficult to be predicted [28].

EPO treated groups showed significant decrease in IL6, TNFa and MDA, while serum level of SOD was significantly increased indicating an antiinflammatory and anti-oxidant effect of EPO treatment. Several studies reported an anti-inflammatory effect of EPO as EPO pre and post treatment significantly decrease polymorphonuclear leukocyte $(\mathrm{PMN})$ infiltration and tissue myeloperoxidase (MPO) activity [ 58] . Others showed that EPO treatment decreased pro-inflammatory cytokines, TNF a IL-6 and NF-Bic in renal I/R [15,59]. The antioxidant effect of EPO was reported to be mediated by inducing intracellular antioxidants as heme oxygenase- 1 and glutathione peroxidase. Other mechanisms of the antioxidant effect of EPO involve tyrosine kinase receptor activation and decrease lipid peroxidation by increasing antioxidant enzymes as catalase and SOD [60,61] . An antiapoptotic effect of EPO was also reported by other researches showing that EPO reduced proximal tubular epithelial cell apoptosis and death by increasing the expression of the anti-apoptotic protein, Bcl-2 and heat shock protein-70 (HSP-70) in sham operated and I/R animals $[6 \mathbf{6 2 , 6 3 ]}$

To our knowledge, the effect of EPO on hepatic tissue after renal I/R injury was not investigated before. However, the direct effect of EPO on hepatic tissue regeneration was previously investigated and showed that, systemic administration of highdose EPO increases hepatic tissue regeneration after liver resection and improved liver function and histopathology [20]. In addition, a reduction of hepatic apoptosis and necrosis was reported in EPO-treated graft livers $[\mathbf{2 1 , 2 2}]$ which might indicate a possible role for EPO in protection of the liver following renal I/R injury.

It worth mentioning that, MAP was significantly decreased in I/R group relative to sham group. The same results were found for IPC and IPOC groups. In EPO treated groups, MAP was significantly increased back to normal levels of sham group. EPO treatment was previously described to affect arterial blood pressure inducing hypertension in 20-30\% of renal patients [64,65]. However this increase was reported in chronic EPO administration and was related to increase in haematocrit value, blood viscosity and improved vascular reactivity due to correction of anaemia [66,67]. All these factors require long term EPO treatment, while in our study single dose of EPO was given so, other mechanisms could be involved. Acute EPO administration was reported to be associated with an increase in endothelin-1 (ET-1) level in renal I/R injury [68]. EPO was found to stimulate ET-1 release in cultured endothelial cells [69] and in isolated hind legs of rats [70]. Endothelin-1 was also reported to increase in mice that overexpress erythropoietin [71] which might have increased MAP back to normal.

The results also showed that, IPOC significantly protected the kidney and liver from damage after renal ischemia reperfusion as indicated by significant decrease in serum creatinine, blood urea, BUN, AST and ALT levels. Renal and hepatic injury score showed a significant decrease too. An anti-inflammatory and anti-oxidant mechanism might be involved in this protective effect as indicated by the significant decrease in IL6, TNF a and MDA and the significant increase in SOD. Previous studies revealed that, IPOC has a significant renal protective effect in renal I/R injury with reduction of inflammatory mediators and oxidative stress markers $[34,56,72]$. Similar to our study, the protective effect of renal IPOC can extends to the liver as was reported by Sefie et al., [6] who demonstrated that, ischemic post- conditioning applied to the kidney induced a significant improvement in renal and hepatic function and morphology after renal $\mathrm{I} / \mathrm{R}$ injury and also reported a decrease in hepatic MDA and an increase in hepatic SOD levels.

In IPC-I/R group, ischemic pre-conditioning of the kidney provided reno-protective effect proved by a significant decrease in serum creatinine, blood urea and BUN with significant decrease in renal tissue injury score. The effect of IPC applied locally on the kidney during renal I/R was frequently investigated with promising results as IPC was reported to attenuate post-ischemic deterioration of renal function and histopathology [73-76]. In contrast, Rebeiro et al., [77] found that local IPC followed by renal ischemia impaired renal function more than ischemia alone. Opposite to our results, they found a significant increase in blood urea and serum creatinine and non-significant change in SOD and catalase in IPC-I/R group relative to I/R group. The author assumed that, the cause of this conflict might be due to that, they conducted IPC protocol of $15 \mathrm{~min}$ ischemic intervals which is too long and can cause ischemia per se [77] 
The commonly described mechanisms of the protective effect of IPC involve molecules including bradykinin, adenosine, endothelin and opioids which trigger intra-cellular signalling pathways as MAPK, protein kinase C, NF- $(x \mathrm{~B}$ and heat shock factor -1 [78]. In addition, decreases cellular energy demand during ischemia by maintaining high ATP levels, lowering glycolysis levels and preserved function of $\mathrm{Na}+\mathrm{K}+\mathrm{ATPase}$ pump [31,79]. Moreover, ischemic preconditioning was reported to have a protective effect on renal function by decreasing the expression of renal adhesion molecules including, P-Selectin, E-Selectin and ICAM-1 [74].

This study also showed that the protective effect of IPC didn't involve the liver as there is no significant change in serum AST, ALT and hepatic injury score was noticed relative to I/R group. IPCI/R group revealed a significant decrease of IL6 and TNFa but no significant change in MDA and SOD. So, we can assume that the protective effect of IPC protocol conducted in this study was not strong enough to induce remote hepatic protection and was localized only in the kidney. One possible explanation of this result is that blood and specimens were collected $12 \mathrm{~h}$ after IPC-I/R protocol. Previous studies described that IPC provides protective effects immediately following the IPC stimulus and lasts for 2-4h after which it disappears then the protective effect reappear 24-72h later, termed the Second Window of Protection or delayed IPC [80]. So, the early effect of IPC lasted only for short time which might not be enough to provide remote hepatic protection and longer time is needed for the long term effect of IPC to appear. Another possibility is the duration of ischemia and reperfusion intervals of IPC protocol conducted in our study as Fan and his team [74] found that the protective effect of IPC on the kidney would decline with the prolongation of the reperfusion interval and declared that, the protective effect of IPC would be lost if ischemic intervals are separated by more than $10 \mathrm{~min}$ of reperfusion. From the previous we can suggest that using shorter reperfusion intervals than the intervals used in our study (10min) might give better response.

The greater protective effect of IPOC on renal and hepatic injury relative to IPC detected in this study might be explained by previous reports indicated that, in ischemia reperfusion, tissue damage is not limited to ischemia but with tissue re-oxygenation tissue damage is worsened by the reperfusion injury that is even more deleterious than ischemia $[\mathbf{8 1 , 8 2}]$. So, IPOC through mechanical alteration of the hydrodynamics of reperfusion $[\mathbf{8 3 , 8 4}]$ can confer some degree of protection or higher repair potential [31] to counteract reperfusion induced adverse effects with better results relative to IPC which decrease the ischemic rather than the reperfusion induced tissue injury. In contrast to this result, it had been shown that ischemic post-conditioning is as effective as ischemic preconditioning in preventing ischemia-reperfusion injury in several tissues $[\mathbf{2 9 , 3 0 , 8 5}$. Others reported that, ischemic post-conditioning could not attenuate the damage caused by ischemia reperfusion when analysed in a hyper acute phase [86]. This conflict might be attributed to different protocols of IPC and IPOC applied in these studies or these protocols were applied on different tissues which mean different blood supply, energy demand and oxygen requirements and so different response to ischemia reperfusion.

EPO treatment, either before or after renal ischemia reperfusion, provided protection against renal and hepatic injury with better results for EPO pre-treatment. Both ischemic pre and postconditioning attenuated renal ischemia reperfusion injury, while hepatic injury was improved only by ischemicpredictable. Further studies on the effect of chronic administration or different doses of EPO are needed. Studying different protocols of IPC and IPOC as regard timing and duration of ischemia and reperfusion intervals and time point of examination is of great interest. Whether these protocols are effective in human or not, needs further investigation.

Acknowledgment: To Prof. Kamal Eleshishi, Pathology Department, Faculty of Medicine, Zagazig University, for performing the histopathological study.

\section{References}

1- SANADA S., KOMURO I. and KITAKAZE M.: Pathophysiology of myocardial reperfusion injury: Preconditioning, postconditioning, and translational aspects of protective measures. Am. J. Physiol. Heart. Circ. Physiol., 301 (5): 1723-4, 2011.

2- SNOEIJS M.G., VINK H., VOESTEN N., CHRISTIAANS M.H., DAEMEN J.W., PEPPELENBOSCH A.G, TORDOIR J.H., PEUTZ-KOOTSTRA C.J., BUURMAN W.A., SCHURINK G.W. and HEURN L.W.: Acute ischemic injury to the renal microvasculature in human kidney transplantation. Am. J. Physiol. Renal Physiol., 299 (10): F1134-40, 2010.

3- WANG Y., SETO S.W. and GOLLEDGE J.: Therapeutic effects of renal denervation on renal failure. Curr. Neurovasc. Res., 10 (2): 172-84, 2013.

4- KELLUM J.A., UNRUH M.L. and MURUGAN R.: Acute kidney injury. BMJ Clinical Evidence.2011: 2001, 2011.

5- MALEK M. and NEMATBAKHSH M.: Renal ischemia/ reperfusion injury; from pathophysiology to treatment. J. Renal. Inj. Prev., 4 (2): 20-27, 2015. 
6- SEIFI B., KADKHODAEE M., NAJAFI A. and MAHMOUDI A.: Protection of liver as a remote organ after renal ischemia-reperfusion injury by renal ischemic Postconditioning. International Journal of Nephrology, 4 pages, 2014.

7- ARDALAN M., ESTAKHRI R., HAJIPOUR B. ANSARIN K., ASL N.A., NASIRIZADE M.R., AZAR A.N., GHORBANIHAGHJOU A., VATANKHAH A.M. and ESMAILI H.A.: Erythropoietin ameliorates oxidative Stress and tissue injury following renal ischemia/ reperfusion in rat, kidney and lung. Med. Princ. Pract., 22 (1): 70-74, 2013.

8- ZHANG J., YU-RONG Z.O.U., ZHONG X., DENG H.D.F, LEI P.U., PENG K. and WANG L.: Erythropoietin pretreatment ameliorates renal ischemia-reperfusion injury by activating PI3K/Akt signaling. Asian Pacific Society of Nephrology, 20 (4): 266-272, 2015.

9- HAUSENLOY D.J. and YELLON D.M.: Myocardial ischemia-reperfusion injury a neglected therapeutic target. J. Clin. Invest., 123 (1): 92-100, 2013.

10- GRAMS M.E. and RABB H.: The distant organ effects of acute kidney injury. Kidney Int., 81 (10): 942-948, 2012.

11- YAP S.C. and LEE H.T.: Acute kidney injury and extra renal organ dysfunction. The American Society of Anesthesiologists, 116 (5): 1139-48, 2012.

12- GOLAB F., KADKHODAEE M. and ZAHMATKESH M.: Ischemic and non-ischemic acute kidney injury cause hepatic damage. International Society of Nephrology, 75 (8) 783-792, 2009.

13- WHITE L.E. and HASSOUN H.T.: Inflammatory mechanisms of organ crosstalk during ischemic acute kidney injury. International Journal of Nephrology, 505197, 8 pages, 2012.

14- SHARFUDDIN A. and MOLITORIS B.: Pathophysiology of ischemic acute kidney Injury Nat. Rev. Nephrol., 7 (4): 189-200, 2011.

15- HU L., YANG C., ZHAO T., XU M., TANG Q., YANG B., RONG R. and ZHU T.: Erythropoietin ameliorates renal ischemia and reperfusion injury via inhibiting tubuleinterstitial inflammation. J. Surg. Res., 176: 260, 2012.

16- OBA S., SUZUKI E., NISHIMATSU H., KUMANO S., HOSODA C., HOMMA Y. and HIRATA Y.: Renoprotective effect of erythropoietin in ischemia/reperfusion injury: Possible roles of the Akt/endothelial nitric oxide synthase-dependent pathway. Int. J. Urol., 19: 248, 2012.

17- KWON M.S., KIM M.H., KIM S.H., PARK K.D., YOO S.H., OH I.U., PARK S. and SEO Y.: Erythropoietin exerts cell protective effect by activating PI3K/Akt and MAPK pathways in C6 Cells. Neurol. Res., 36: 215-23, 2014.

18-ELSHIEKH M., KADKHODAEE M. and SEIFI B.: Erythropoietin a promising agent in the prevention of renal ischemia reperfusion injury. Ann. Res. Antioxid, 2 (2): $\mathrm{e} 01,2017$.

19- BRINES M. and CERAMI A.: Erythropoietin-mediated tissue protection: Reducing collateral damage from the primary injury response. J. Intern. Med., 264: 405-32, 2008.

20- GUL M., CÖMERT M., ÇAKMAK G.K, KERTIS G., UGURBAS E. and ONER M.O.: Effect of erythropoietin on liver regeneration in an experimental model of partial Hepatectomy. International Journal of Surgery, 11: 5963, 2013.

21- SCHMEDING M., BOAS-KNOOP S., LIPPERT S., RUEHL M., SOMASUNDARAM R., DAGDELEN T., NEUHAUS P. and NEUMANN U.P.: Erythropoietin promotes hepatic regeneration after extended liver resection in rats. Journal of Gastroenterology and Hepatology, 23: 1125-1131, 2008

22- SCHMEDING M., HUNOLD G., ARIYAKHAGORN V., RADEMACHER S., BOAS-KNOOP S., LIPPERT S., NEUHAUS P. and NEUMANN U.P.: Erythropoietin reduces ischemia-reperfusion injury after liver transplantation in rats. European Society for Organ Transplantation., 22: 738-746, 2009.

23- GAO J., ZHAO L., WANG Y., TENG Q., LIANG L. and ZHANG J.: Effect of limb ischemic preconditioning on myocardial apoptosis-related proteins in ischemiareperfusion injury. Exp. Ther. Med., 5 (5): 1305-9, 2013.

24- SANTOS C.H., AYDOS R.D., NOGUEIRA N.E., MIIJI L.N., CASSINO P.C., AHMED I.I., CALHEIROS N.M., GARCIA M. and SILVA A.F.: Importance of duration and number of ischemic postconditioning cycles in preventing reperfusion mesenteric injuries. Experimental study in rats. Acta. Cir. Bras., 30 (10): 709-14, 2015.

25- YAMAKI I.N., PONTES R.V.S., COSTA F.L.S., YAMAKI V.N., TEIXEIRA R.K.C., YASOJIMA E.Y. and BRITO M.V.H.: Kidney ischemia and reperfusion syndrome: effect of lidocaine and local postconditioning. Rev. Col. Bras. Cir., 43 (5): 348-53, 2016.

26- HAUSENLOY D.J. and YELLON D.M.: Remote ischemic preconditioning: underlying mechanisms and clinical application. Cardiovasc Res., 79 (3): 377-86, 2008.

27- KARAKOYUN R., KOKSOY C., YILMAZ T.U., ALTUN H., BANLI O., ALBAYRAK A., ALPER M. and SENER Z.: The Angiogenic Effects of Ischemic Conditioning in Experimental Critical Limb Ischemia. European Journal of Vascular and Endovascular Surgery, 47 (2): 172-179, 2014.

28- BRITO M.V.H., YASOJIMA E.Y., MACHADO A.A., SILVEIRA M.P.P.R., TEIXEIRA R.K.C., YAMAKI V.N. and COSTA F.L.S.: Different protocols of postconditioning do not attenuate mesenteric ischemiareperfusion injury after short term reperfusion. Arq. Bras. Cir. Dig., 30 (1): 27-29, 2017.

29- SANTOS C.H.M., GOMES O.M., PONTES J.C.D.V. MIIJI L.N.O. and BISPO M.A.F.: The ischemic preconditioning and postconditioning effect on the intestinal mucosa of rats undergoing mesenteric ischemia/reperfusion procedure. Acta. Cir. Bras., 23 (1): 22-8, 2008.

30- CHU W., LI S., WANG S., YAN A. and NIE L.: Ischemic postconditioning provides protection against ischemiareperfusion injury in intestines of rats. Int. J. Clin. Exp. Pathol., 8 (6): 6474-81, 2015.

31-THURETA R., YVESA T. S, TILLOUD X., CHATAURETA N., THUILLIERA R., BARROUA B. and BILLAULTA C.: Ischemic pre- and post-conditioning: current clinical applications. Progrès en urologie., 24: S56-S61, 2014.

32- GONG H., WANG W., KWON T.H., JONASSEN T., LI C., RING T., FROKIAER J. and NIELSEN S.: EPO and alpha-MSH prevent ischemia-reperfusion-induced down- 
regulation of AQPs and sodium transporters in rat kidney. Kidney. Int., 66: 683-95, 2004.

33- LI F., KIMURA S., NISHIYAMA A., RAHMAN M., ZHANG G. and ABE Y.: Ischemic pre-conditioning protects post-ischemic renal function in anesthetized dogs: Role of adenosine and adenine nucleotides. Acta Pharmacologica Sinica., 26 (7): 851-859, 2005.

34- CHEN H., XING B., LIU X., ZHAN B., ZHOU J., ZHU $H$. and CHEN Z.: Ischemic postconditioning inhibits apoptosis after renal ischemia/reperfusion injury in rat. Transpl. Int., 21: 364-371, 2008.

35- LEE H.T. and EMALA C.W.: Protective effects of renal ischemic preconditioning and adenosine pre-treatment: role of A1 and A3 receptors. Am .J. Physiol. Renal. Physiol., 278: F380-F387, 2000.

36- MILLER F.N. and WIEGMAN D.L.: Anesthesia-induced alteration of small vessel response to norepinephrine. Eur. J. Pharmacol., 44 (4): 331-7, 1977.

37- PARASURAMAN S. and RAVEENDRAN R.: Measurement of invasive blood pressure in rats. J. Pharmacol. Pharmacother., 3 (2): 172-77, 2012.

38- MURRAY R.L.: Nonprotein compounds, In: KAPLAN LA AND PESCE AJ (editors), Clinical chemistry: Theory, analysis and co-relation, Mosby CV Toranto, 1230-68, 1984.

39- KAPLAN A.: Urea Kaplan A. et al., Clin. Chem. the C.V. Mosby Co.,St Louis. Toronto. Princeton, 1257-1260, 437 and $418,1984$.

40- FLAVIO V. and WILLIAM J.C.: Long term renal function in kidney donors. Transplantation, 36 (6): 626., 1983.

41- REC J. S.: Estimation of serum ALT. J. Clin. Biochem., 8: 658,1970 .

42- ENGELBERTS I., MÖLLER A., SCHOEN G.J., VAN DER LINDEN C.J. and BUURMAN W.A.: Evaluation of measurement of human TNF in plasma by ELISA. Lymphokine Cytokine Res., 10 (1-2): 69-76, 1991.

43- ABU-AMARA M., YANG S.Y., QUAGLIA A., ROWLEY P., TAPURIA N., SEIFALIAN A.M., FULLER B.J. and DAVIDSON B.R.: Effect of Remote Ischemic Preconditioning on Liver Ischemia/Reperfusion Injury Using, a New Mouse Model. Liver Transplantation, 17: 70-82, 2011.

44- NAJAFI H., OWJI S.M., KAMALI-SARVESTANI E. and MOOSAVI S.M.: A1-adenosine receptor activation has biphasic roles in development of acute kidney injury at 4 and $24 \mathrm{~h}$ of reperfusion following ischemia in rats. Exp. Physiol., 101: 913-931, 2016.

45- YAMAKI V.N., GONCALVES T.B., COELHO J.V.B., PONTES R.V.S, COSTA F.L.S. and BRITO M.V.H.: Efeito protetor do per-condicionamento isquêmico remoto nas lesões da síndrome de isquemia e reperfusão renal em ratos. Rev. Col. Bras. Cir., 39 (6): 529-33, 2012.

46- FAUBEL S.: Pulmonary complications after acute kidney injury. Adv. Chronic. Kidney. Dis., 15: 284-296, 2008.

47- KO G.J., RABB H. and HASSOUN H.T.: Kidney-lung crosstalk in the critically ill patient. Blood Purif., 28: 7583, 2009.

48- PARK S.W., CHEN S.W., KIM M., BROWN K.M., KOLLS J.K., D'AGATI D.V. and LEE H.T.: Cytokines induce small intestine and liver injury after renal ischemia or nephrectomy. Lab. Invest., 91 (1): 63-84, 2011.

49- THAKAR C.V., CHRISTIANSON A., FREYBERG R., PETER A. and MARTA R.L.: Incidence and outcomes of acute kidney injury in intensive care units: A veterans administration study. Crit. Care. Med., 37: 2552-2558, 2009.

50- DOI K. and RABB H.: Impact of acute kidney injury on distant organ function: Recent findings and potential therapeutic targets. Official Journal of International Society of Nephrology, 89 ( 3): 555-564, 2016.

51- FADILLIOGLU E., KURCER Z., PARLAKPINAR H., IRAZ M. and GURSUL C.: Melatonin treatment against remote organ injury induced by renal ischemia reperfusion injury in diabetes mellitus. Arch. Pharm. Res., 31: 705712, 2008 .

52- ANDRÉS-HERNANDO A., ALTMANN C., AHUJA N., LANASPA A.M., NEMENOFF R., HE Z., ISHIMOTO T., SIMPSON P.A., WEISER-EVANS M.C., BACALJA J. and FAUBEL S.: Splenectomy exacerbates lung injury after ischemic acute kidney injury in mice. Am. J. Physiol. Renal. Physiol., 301: F907-F91, 2011.

53- PARK S.W., KIM M., KIM J.Y., LEE H.T., HAM A.M BROWN K.M., MORI-AKIYAMA Y., QUELLETTE A.J., and D'AGATI D.V.: Paneth cell-mediated multiorgan dysfunction after acute kidney injury. J. Immunol., 189: 5421-5433, 2012.

54- ANDRES-HERNANDO A., DURSUN B., ALTMANN C., AHUJA N., HE Z., BHARGAVA R., EDELSTEIN C. E., JANI A., HOKE T. S., KLEIN C and FAUBEL S.: Cytokine production increases and cytokine clearance decreases in mice with bilateral nephrectomy. Nephrol. Dial. Transplant., 27: 4339-4347, 2012

55- HASSOUN H.T., LIE M.L., GRIGORYEV D.N., LIU M., TUDER R.M. and RABB H.: Kidney ischemia-reperfusion injury induces caspase-dependent pulmonary apoptosis. Am. J. Physiol. Renal. Physiol., 297: F125-F137, 2009.

56- JIANG B.T., CHEN Q.Z., GUO Z.H., ZOU W.E., CHEN $X$. and ZHA W.L.: Ischemic post-conditioning attenuates renal ischemic reperfusion injury via down-regulation of toll-like receptor 4 in diabetic rats. Renal Failure, 38: 9, 1425-1431, 2016

57- CHEN X., WANG C.C., SONG S.M., WEI S.Y., LI J.S., ZHAO S.L. and LI B.: The administration of erythropoietin attenuates kidney injury induced by ischemia/reperfusion with increased activation of $\mathrm{Wnt} / \mathrm{B}$-catenin signaling. $\mathrm{J}$. Formos. Med. Assoc., 114: 430-7, 2015.

58- KINSEY G.R., LI L. and OKUSA M.D.: Inflammation in acute kidney injury. Nephron. Exp. Nephrol., 109 (4): e102-e107, 2008.

59- DIWAN V., KANT R., JAGGI A.S., SINGH N. and SINGH D.: Signal mechanism activated by erythropoietin preconditioning and remote renal preconditioning-induced cardioprotection. Mol. Cell. Biochem., 315 (1-2): 195-201, 2008.

60- BAHCEKAPILI N., UZÜM G., GÖKKUSU C., KURU A. and ZIYLAN Y.Z.: The relationship between erythropoietin pre-treatment with blood brain barrier and lipid peroxidation after ischemia/reperfusion in rats. Life Sci., 80 (14): 1245-1251, 2007. 
61- YAZIHAN N., ATAOLU H., YENER B. and AYDIN C. Erythropoietin attenuates hydrogen peroxide-induced damage of hepatocytes. Turk. J. Gastroenterol., 18 (4): 239-244, 2007.

62- OKADA T., SAWADA T. and KUBOTA K.: Erythropoietin has strong reno-protective effects against ischemiareperfusion injury in a murine model. Transplantation, 84 (4): 504-510, 2007.

63- YAZIHAN N. and KAVAS G.O.: Protective Effect of Erythropoietin in Renal Ischemia-Reperfusion Injury. The Open Drug Discovery Journal, 2: 3-7 3, 2010.

64- LEE M.S., LEE J.S. and LEE J.Y.: Prevention of erythropoietin associated hypertension. Hypertension, 50: 43945, 2007.

65- NOSHAD H.: Blood Pressure Increase after Erythropoietin Injection in Hemodialysis and Predialysis Patients. Iranian Journal of Kidney Diseases, 7 (3): 220-5, 2013.

66- KRAPF R. and HULTER H.N.: Arterial hypertension induced by erythropoietin and erythropoiesis-stimulating agents (ESA). Clin. J. Am. Soc. Nephrol., 4: 470-80, 2009.

67- TOMCZAK-WATRAS W., STROZECKI P., ZUCHORA Z., SZEFER J. and MANITIUS J.: Influence of the 6month anaemia therapy with erythropoietin on renal function and some hemodynamic parameters in predialysis patients. Pol. Arch. Med. Wewn., 119: 45-51, 2009.

68- HUSSIEN N. and EMAM H.T.: The potential protective effects of erythropoietin and estrogen on renal ischemia reperfusion injury in ovariectomized rats. Alexandria Journal of Medicine, 52: 325-335, 2016.

69- CARLINI R.G., DUSSO A.S., OBIALO C.I., ALVAREZ U.M. and ROTHSTEIN M.: Recombinant human erythropoietin (rHuEPO) increases endothelin-1 release by endothelial cells. Kidney. Int., 43: 1010-4, 1993.

70- KATOH K., MIZUNO K., HASHIMOTO S., OKAZAKI K., ASAHI K., KURIKI M., YAMADA D., and FUKUCHI S.: Direct evidence for erythropoietin-induced release of endothelin from peripheral vascular tissue. Life Sci., 54: PL253-259, 1994.

71- QUASCHNING T., RUSCHIZKA F., STALLMACH T., SHAW S., MORAWIETZ H., GOETTSCH W., HERMANN M., SLOWINSKI T., THEURING F., HOCHER B., LÜSCHER T.F., and GASSMANN M.: Eryhropoietin induced excessive erythrocytosis activates the tissue endothelin system in mice. FASEB. J., 17: 259-261, 2003.

72- ELDAIF S.M., DENEVE J.A., WANG N.P., JIANG R., MOSUNJAC M., MUTRIE C.J., GUYTON R.A., ZHAO Z.Q. and VINTEN-JOHANSEN J.: Attenuation of renal ischemia-reperfusion injury by postconditioning involves adenosine receptor and protein kinase $\mathrm{C}$ activation. European Society for Organ Transplantation, 23: 217-226, 2010.

73- HAUSENLOY D.J. and YELLON D.M.: The therapeutic potential of ischemic conditioning: an update. Nat. Rev. Cardiol., 8 (11): 619-29, 2011.

74- FAN L., HE L., CAO Z., XIANG J. and LIU L.: Effect of ischemia preconditioning on renal ischemia/reperfusion injury in rats. Int. Braz. J. Urol., 38 (6): 842-854, 2012.

75- WEVER K.E., MENTING T.P., ROVERS M., VAN DER VLIET J.A., RONGEN G.A., MASEREEUW R., RITSKES-HOITINGA M., HOOIJMANS C.R. and WARLÉ M.: Ischemic Preconditioning in the Animal Kidney, a Systematic Review and Meta-Analysis. PLoS ONE, 7 (2): e32296, 2012.

76- ELSHIEKH M., KADKHODAEE M., SEIFI B., RANJBARAN M. and AHGHARI P.: Ameliorative Effect of Recombinant Human Erythropoietin and Ischemic Preconditioning on Renal Ischemia Reperfusion Injury in Rats. Nephro. Urol. Mon., 7 (6): e31152, 2015.

77- RIBEIRO G.B., SANTOS E.B., BONA S.R., SCHAEFER P.G., GARCEZTA., RABOLINI E.B., SMANIOTTO G.P., MARRONI N.P. and CORSO C.O.: The effects of local ischemic preconditioning and topical hypothermia in renal ischemia/reperfusion injury in rats. Acta. Cir. Bras., 32 (10): 816-826, 2017.

78- SELZNER N., BOEHNERT M. and SELZNER M.: Preconditioning, postconditioning, and remote conditioning in solid organ transplantation: Basic mechanisms and translational applications. Transplant Rev. (Orlando.), 26 (2): 115-24, 2012.

79- PASUPATHY S. and HOMER-VANNIASINKAM S.: Surgical implications of is- chemic preconditioning. Arch. Surg., 140 (4): 405-410, 2005.

80- HAUSENLOY D.J. and YELLON D.M.: The Second Window of Preconditioning (SWOP). Where Are We Now? Cardiovasc Drugs Ther., 24: 235-254, 2010.

81- KAHLOW B.S., NERY R.A., SKARE T.L., RIBAS C.A., RAMOS G.P. and PETISCO R.D.: On vascular stenosis, restenosis and mannose binding lecthin. Arq. Bras. Cir. Dig. Mar., 29 (1): 57-9, 2016.

82-ZANCHET M.V., SILVA L.L., MATIAS J.E. and COELHO J.C.: Post-reperfusion liver biopsy and its value in predicting mortality and graft dysfunction after liver transplantation. Arq. Bras. Cir. Dig., 29 (3): 189-193, 2016.

83- JIANG B., LIU X., CHEN H., LIU D., KUANG Y, XING B. and CHEN Z.: Ischemic postconditioning attenuates renal ischemic/reperfusion injury in mongrel dogs. Urology, 76: $1519-7,2010$.

84- KNUDSEN A.R., KANNERUP A.S., DICH R., FUNCHJENSEN P., GRONBAEK H., KRUHOFFER M. and MORTENSEN F.V.: Ischemic pre and postconditioning has pronounced effects on gene expression profiles in the rat liver after ischemia/reperfusion. Am. J. Physiol. Gastrointest Liver Physiol., 303: G482-G489, 2012.

85- LINTZ J.A., DALIO M.B., JOVILIANO E.E. and PICCINATO C.E.: Ischemic pre and postconditioning in skeletal muscle injury produced by ischemia and reperfusion in rats. Acta. Cir. Bras., 28 (6): 441-6, 2013.

86- BRETZ B., BLAZE C., PARRY N. and KUDEJ R.K.: Ischemic postconditioning does not attenuate ischemiareperfusion injury of rabbit small intestine. Vet. Surg., 39 (2): 216-23, 2010. 


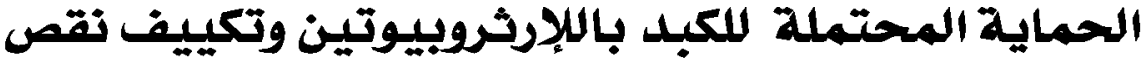

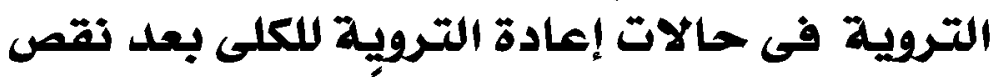

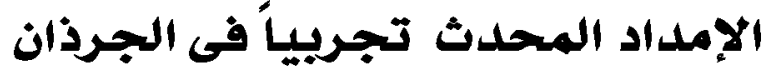

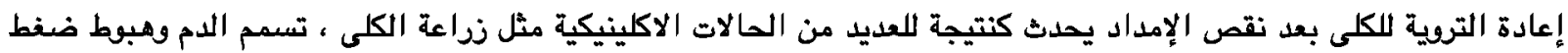

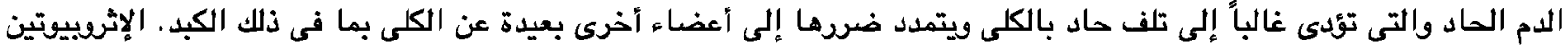

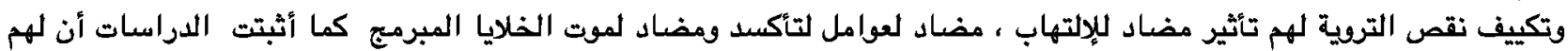

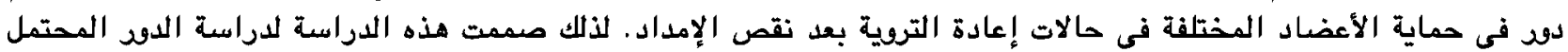
للإرثربيوتين وتكييف نقص التروية فى حماية الكبد سواء تم تطبيقهم قبل أو بعد إعادة التروية للكلى بعد نقص الإمداد وكذلك إيضاح بعض الآليات المحتملة لهذا التأثير.

أجريت هذه الدراسة على عدد الح من ذكور الجرذان البيضلاء البالغة وتم نقسيمهم إلى آمبحموعات مشساوية:

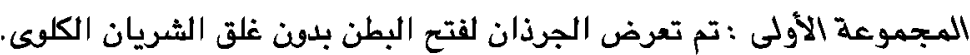

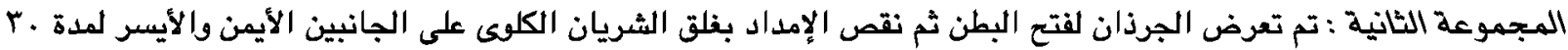

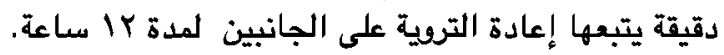
المجموعة الثالثة : تم حقن الجرذان بالإبيوتين (...1 وحدة/كجم) .ب دقيقة قبل تعرضها لنفس الإجراءات التى تعرضت لها لهاءئ المجموعة الثانية.

المجموعة الرابعة: تم حقن الجرذان بالإبيوتين (..1 وحدة/كجم) ـ7 دقيقة قبل تعرضها لنفس الإجراءات التى تعرضت لها المجموعة الثانية.

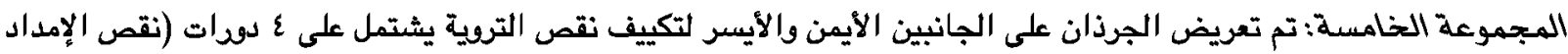

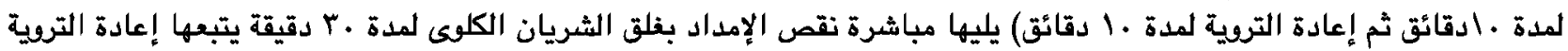

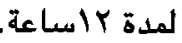

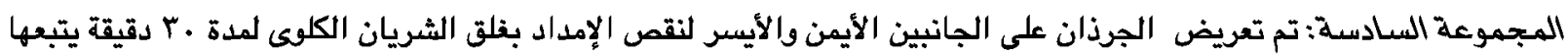

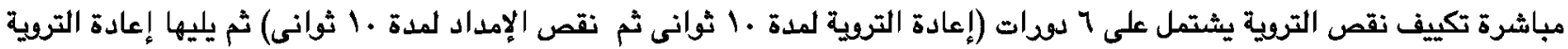
المدة باعرة سكاعة.

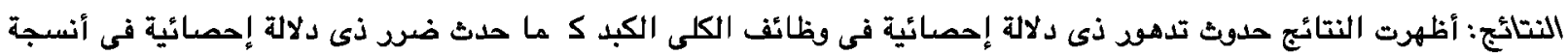

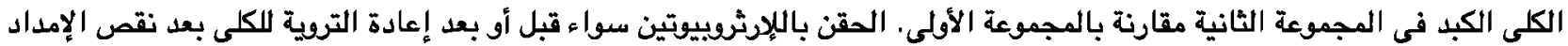

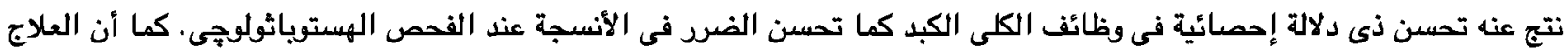

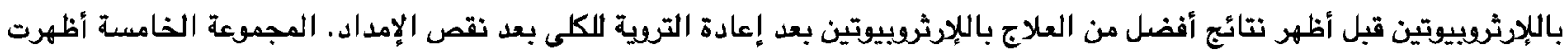

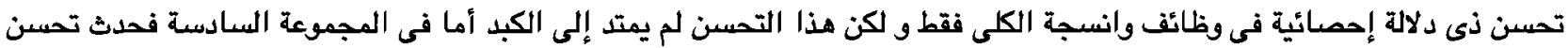

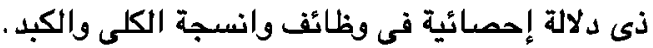

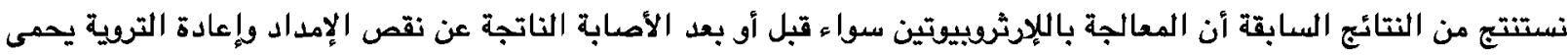

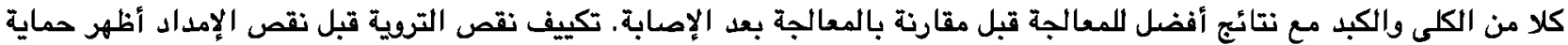

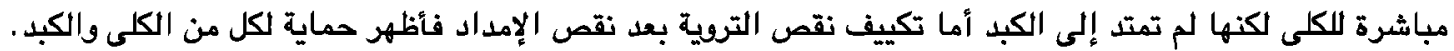

